\title{
A TRAGÉDIA DOS COMUNS E AS QUESTÕES SANITÁRIAS EM TEMPOS DE COVID-19: REFLEXÕES PARA REPENSAR O DIREITO À CIDADE
}

The Tragedy Of The Commons And Health Issues In Times Of Covid-19: Reflections For Rethinking The Right To The City

\section{Caroline Vieira Ruschel}

Universidade do Vale do Itajaí, Itajaí, SC, Brasil

Lattes: http://lattes.cnpq.br/4746435495067413 Orcid: https://orcid.org/0000-0002-4263-850X

E-mail: carollineruschel@carollineruschel.com

\section{Geraldo Milioli}

Universidade do Extremo Sul Catarinense - UNESC, Criciúma, SC, Brasil Lattes: http://lattes.cnpq.br/2731977737884111 Orcid: https://orcid.org/0000-0001-5224-2042

E-mail:gmi@unesc.net

\section{Izes Regina de Oliveira}

Universidade do Extremo Sul Catarinense - UNESC , Criciúma, SC, Brasil

Lattes: http://lattes.cnpq.br/0186904659069663 Orcid: https://orcid.org/0000-0002-7581-7432

E-mail:izesdeoliveira@hotmail.com

Trabalho enviado em 11 de maio de 2020 e aceito em 16 de junho de 2021

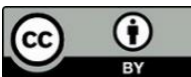

This work is licensed under a Creative Commons Attribution 4.0 International License. 


\section{RESUMO}

O artigo, de cunho interdisciplinar, reflete estratégias sustentáveis à minimização dos problemas sanitários urbanos, aclarados com a pandemia da Covid-19. O objetivo é refletir sobre o direito à cidade a partir da perspectiva complexa. Aponta alguns problemas urbanos, esclarece base teórica, limites e possibilidades sobre o urbanismo com preceitos e respostas para uma cidade sustentável e o papel do direito. Discorre sobre o 'comum' e a dificuldade dos indivíduos de agirem para minimizar os efeitos da pandemia no Brasil, expõe a insustentabilidade do modelo urbano global, entre desigualdade, informalidade e insegurança que propiciam a expansão da Covid-19. Reflete o agravamento da vida das pessoas nas cidades e dos impactos do planeta conforme a tragédia dos comuns denuncia. Como resultado, a complexidade ressalta a responsabilidade pelo coletivo, contrário às ações da sociedade contemporânea que fragmenta o todo e bloqueia o agir coletivo. O conceito do 'comum' analisado a partir da biologia da cognição e da complexidade, expande com a praxis dos seres humanos para a construção do senso de comunidade. O método do artigo é o dedutivo, parte de conceitos gerais para chegar a conclusões específicas, com a técnica bibliográfica, documental e experiência intrínseca.

Palavras-chave: Consciência coletiva; Limites do direito; Biologia da cognição; Pensamento complexo; Cidade sustentável.

\section{ABSTRACT}

The interdisciplinary article reflects sustainable strategies for minimizing urban health problems, clarified with the Covid-19 pandemic. The objective is to reflect on the right to the city from a complex perspective. It points out some urban problems, clarifies theoretical basis, limits and possibilities about urbanism with precepts and answers for a sustainable city and the role of law. It discusses the 'common' and the difficulty of individuals to act to minimize the effects of the pandemic in Brazil, exposes the unsustainability of the global urban model between inequality, informality and insecurity that propitiate the expansion of Covid-19. It reflects the aggravation of people's lives in the cities and the impacts of the planet according to the tragedy of the commons denounces. As a result, complexity highlights the responsibility for the collective, contrary to the actions of contemporary society that fragment the whole and block collective action. The concept of the 'common' analyzed from the biology of cognition and complexity, expands with the praxis of human beings to build a sense of community. The article method is deductive, based on general concepts to reach specific conclusions, using bibliographic, documentary technique and intrinsic experience.

Keywords: Collective awareness; Limits of the right; Biology of cognition; Complex thinking; Sustainable city. 


\section{INTRODUÇÃO}

O objetivo desse artigo é refletir sobre o direito à cidade a partir de perspectiva científica fundamentada em diferentes preceitos que o pensamento complexo (MORIN, 2005a, 2005b, 2005c, 2005d, 2005e, 2005f, 2011) abarca. Tal investigação faz-se necessária, em vista das dificuldades de ação individual em prol do coletivo, fato que dificulta a vida das pessoas na cidade, suas relações entre si e com a natureza, trazendo conflitos e problemas sanitários e ecológicos, como os ressaltados durante a pandemia da Covid-19.

O objeto do presente estudo aponta a emergência de pensar estratégias arquitetônicas e urbanísticas mais sustentáveis para as cidades. Assim, diferentes modelos urbanos e técnicas sustentáveis precisam entrar na pauta da discussão da política urbana e do direito à cidade, pois urge a necessidade de minimizar os problemas sanitários e averiguar o direito à moradia, interconectados a problemas socioambientais, em função da pandemia e de outros eventuais contágios.

Nesse sentido, a pesquisa busca responder a seguinte pergunta: O direito à cidade auxilia na construção de cidades que supõem saúde e qualidade de vida para os habitantes?

Este artigo distingue uma cidade que preconiza qualidade de vida e saúde aos habitantes, como aquela em que há interdependência ecológica com os indivíduos os quais agem e retroagem em seu ambiente (MORIN, 2005b). Essa cidade é tratada como um ecossistema urbano (NEWMAN; JENNINGS, 2008 ; DE OLIVEIRA e MILIOLI, 2014); onde há envolvimento peculiar das pessoas com a história e a cultura e com o cuidado com a natureza; os espaços públicos são eficientes e suficientes para relacionamentos sociais onde água e árvores, rios e habitats ribeirinhos, jardins e telhados jardins estão vinculados à redução da fadiga mental, ao bom humor, à criatividade, ao aumento dos níveis de saúde física e mental, à redução do estresse, entre outros benefícios (NEWMAN; BATLLEY, 2013); onde o lixo é reciclado e os recursos são usados frugalmente (NEWMAN, 1997). O ecologista social, de Harvard, Edward Osborn Wilson populariza o termo biofilia e Newman e Batlley (2013) conceituam, essa cidade, de biofílica.

A hipótese considerada é que a estrutura formada pelo Direito (leia-se normas, constituições, leis complementares, ordinárias, decretos, princípios) é insuficiente para auxiliar na construção de cidades que permitem qualidade de vida e saúde, pois não considera o paradigma complexo. Por exemplo, as regras gerais válidas em todo o território desconsideram que a geografia e a biodiversidade do Brasil são muito variadas e que cada região também possui costumes socioculturais e demografia diferenciados. A competência local municipal é fundamental para efetivar o direito à 
cidade, onde estão os grandes conflitos de terra e de moradia e onde se dá a política da habitação que tem ingerência sobre as dinâmicas da produção do espaço construído.

Além da dificuldade de se construírem cidades mais justas, o planejamento urbano e a gestão das cidades estão estabelecidos com conceitos do século XIX e início do século XX, seja no desenvolvimento urbano de modo geral (MENEGAT \& ALMEIDA, 2004) ou especificamente nas estruturas sanitárias, no tratamento de rios e suas margens (TUCCI, 2006). Lembrando que a injustiça social se abate sobre o processo de urbanização das cidades brasileiras, quando as periferias se intensificam com a produção da moradia cada vez mais distante do centro urbanizado, segregando e fragmentando o território do município, obrigando ao transporte motorizado.

Nesse sentido, para o artigo atingir seu objetivo geral, explora os tópicos a seguir: a) aponta alguns problemas das cidades relacionados à Covid-19; b) enuncia as bases teóricas da presente pesquisa; c) traz preceitos e sugerir soluções de uma cidade sustentável e ecológica.

A primeira parte aponta problemas sanitários e urbanísticos que agravam a pandemia da Covid19 e outros contágios. As taxas de carências de água e esgotamento sanitário mostram que essas carências estão nas áreas mais pobres, justamente onde falta o direito à cidade, lugares com respostas de maior incidência de mortalidade, não somente por falta de tratamento sanitário básico, como de vegetação, espaços livres e ventilação e insolação habitacional.

No segundo tópico apresenta os pressupostos teóricos utilizados, quais sejam: o Ecossistema Urbano na visão Complexa (MORIN, 1984, 2005a, 2005b, 2005b, 2005c, 2005d, 2005e, 2005f, 2011), a biologia da cognição com a Escola de Santiago (MATURANA; VARELA, 2001); (CAPRA, 2006a, 2006b, 2020) e a tragédia dos comuns (1968), que demonstram que o pensamento individualista, cartesiano e linear limita a percepção do todo e, por conseguinte, da responsabilidade com o coletivo. Destaca-se que o comum é um conceito que vem crescendo nos meios acadêmicos e que precisa ganhar força para expandir na praxis de todos os seres humanos. No entanto, como a sociedade vem se desenvolvendo baseada em pensamento, gestão e planejamento urbano fragmentados, bloqueia o agir de acordo com a complexidade da vida e, consequentemente, ignora o senso de comunidade.

Acredita-se que as descobertas científicas feitas pela Escola de Santiago (biologia da cognição), que demonstram que o sujeito conhece apenas o que ele vivencia e que só se comunica a partir de suas experiências, explica o motivo de tanto desentendimento social e traz a prova de que a estrutura formada pelo direito e pela gestão para proteção e ação nas cidades é limitada e precisa ser repensada. 
Por fim, traz possíveis soluções trabalhadas por arquitetos e urbanistas adeptos de uma cidade sustentável assim como sugestões ao direito à cidade.

A recursividade e a dialógica, típicas do pensamento complexo, serão uma constante na construção do artigo, pois se entende que tanto a cidade, quanto o direito à cidade precisam, recursivamente, ser repensados. Não existe uma lógica, em que um mudando o outro muda, com uma linearidade, mas, ao contrário, uma retroalimentação de ambos com novos valores e paradigmas. No entanto, a construção do artigo se utiliza do método dedutivo. Parte de conceitos gerais para chegar a conclusões específicas com a técnica de pesquisa bibliográfica, documental e experiência intrínseca.

\section{PROBLEMAS DA CIDADE NA PERSPECTIVA SOCIOAMBIENTAL: UMA VISÃO INTERDISCIPLINAR}

É coerente que se honre todas as benesses que a tecnologia fornece para o conforto humano, bem-estar, saúde e comunicação, mas antagonicamente, o mundo está em crise e aponta, moral e eticamente, todos os males causados para o planeta e para as sociedades cujas soluções a ciência conhece. Os problemas socioambientais e a pandemia demonstram a importância do agir individualmente com prática de ações que atinjam a todos, globalmente, de modo a compartilhar os conhecimentos e replicar, pelo mundo, movimentos que mudem a consciência e melhorem a humanidade como um todo.

As modificações que as atividades antrópicas provocam no ecossistema terrestre, movimentando populações humana, animal e vegetal, terras e rios, alteram o ciclo da água e os serviços ecossistêmicos que mantêm o equilíbrio no planeta, que como no pensamento de Capra (2006b), interrompem o fluxo da Teia da Vida. Esses impactos vêm causando a mudança climática, catástrofes socioambientais e quiçá a Covid-19, que segundo pesquisas científicas está ligada à indústria e ao capitalismo entre outros fatores e sua recorrência deverá ser cada vez mais forte. Conforme Capra (2020) "a pandemia é uma resposta biológica da Terra" entre muitas negligências sociais e ambientais.

Jeremy Rifkin sociólogo que se dedica a propor fórmulas que garantam a sobrevivência no planeta, em equilíbrio com o meio ambiente, afirma que a geração de pandemias vem da atividade humana, do recorrente aumento da temperatura na Terra e depredação do solo, que ameaçam a extinção humana e que as pessoas nem sequer sabem. A crise da civilização chegou no ápice e encerra a globalização. Uma nova visão de futuro está em trânsito, que é agir localmente em prol do coletivo, se não se quiser outras pandemias (RIFKIN, 2020). 
Pensamento reforçado por Santos (2020) quando afirma que a "crise permanente" legitima a concentração de riqueza e boicota medidas eficazes para impedir a iminente catástrofe social e ecológica, como se tem vivido nos últimos quarenta anos. A diferença entre a crise e o alerta à pandemia da Covid-19 é que essa atinge a todos, pela alta taxa de transmissão e faz colapsar os sistemas de saúde mais desenvolvidos, por isso, paralisou o mundo e apressa a mudança. Muito embora, os lugares com piores condições sanitárias atinjam muito mais pessoas.

Com a pandemia, a OMS (2020) orienta à quarentena e a higienizar as mãos para desacelerar o contágio. Como obedecer às recomendações quem mora em comunidades? Isso lembra uma visita à Rocinha - Rio de Janeiro, em 2015, quando a guia turística, historiadora, nascida e moradora do local, informa que quando uma gripe ou qualquer doença infecciosa entra na Rocinha, o vizinho ao lado já fica esperando quando baterá a sua porta, porque dissemina um a um. A Rocinha foi urbanizada e humanizada, mas tem grande contingente habitacional, vivendo em casas de parede grudada à parede, com má ventilação e insolação, sem espaços livres tampouco vegetação, junto a outros problemas sanitários de esgoto à céu aberto, jogados num riacho que corre morro abaixo até o mar. Esse cenário insalubre mostra a dificuldade de distanciamento social dessa e de outras populações existentes no Brasil, na América Latina e África.

Além das habitações precárias, o déficit habitacional, segundo o Instituto de Pesquisa Econômica Aplicada - IPEA (2020) é de 14,9\% do total de domicílios, mesmo com todo o investimento efetuado no país. Esse percentual é responsável pela intensificação dos contágios, pois o déficit aponta a coabitação familiar, ou seja, várias gerações da mesma família coabitando a mesma moradia e a densidade habitacional exagerada. Vivem mais pessoas por metro quadrado de residência do que o estabelecido pela saúde e pelas posturas urbanas. Existe uma invisibilidade na questão da moradia no Brasil, que se mantem distante da solução. $O$ direito à moradia antecede e está conectado ao direito à cidade.

Outras zonas de invisibilidade poderão se multiplicar em muitos países da Europa e América do Norte ou outras regiões do mundo, com extrema vulnerabilidade ao vírus, como o exemplo dos refugiados e imigrantes detidos, que vieram à Europa e estão internados no campo de Mória, llha de Lesbos - Grécia. Esses vivem colados uns aos outros, dormem cinco ou seis pessoas num espaço com menos de três metros quadrados com apenas uma torneira de água, sem sabão e pouca comida (SANTOS, 2020). Lembra um Navio Negreiro! A história se repete. 
A pandemia fez ecoar as diferenças dentro das cidades, entre bairros e mesmo entre cidades e países e torna visível a exploração capitalista e a discriminação social, pois, além de muitos lugares terem carência ou ineficiência habitacional, a escassez de água é desumana e há governos que abdicam de assumir salários e alimentos durante a quarentena.

Os números são categóricos, mostram a irracionalidade do mundo que é, no mínimo, alarmante ao destacarem as necessidades de água e saneamento no planeta, que vem aumentando:

- 1.9 bilhões é o número aproximado de pessoas que vivem em áreas onde pode faltar água;

- 5 bilhões de pessoas carecem de acesso a um sistema seguro de saneamento;

- $40 \%$ das pessoas são afetadas pela escassez de água que crescerá com o aumento da temperatura global (NU, 2019);

- Um de cada quatro hospitais do mundo carece de serviços básicos de água;

- Um de cada cinco centros de assistência de saúde falta banheiro ou latrina (OMS, 2019).

Segundo o Instituto Trata Brasil, 48\% da população continua sem coleta de esgoto (SENADO, 2019). Esse dado dá o alerta à Agenda 2030, pois os ODS - Objetivos do Desenvolvimento Sustentável, estão conectados à água. Nos países em desenvolvimento, isso também ocorre, pois $90 \%$ do despejo da água residual é sem tratamento. Resíduos compostos, principalmente, de esgoto, poluição industrial, pesticidas agrícolas e resíduos animais resultam no consumo e no uso de água não tratada e poluída. Mais pessoas morrem hoje por causa da água poluída e contaminada do que por todas as formas de violência, inclusive as guerras: 1,8 milhões de crianças com menos de 5 anos de idade e 2,2 milhões de pessoas morrem anualmente por ingestão de água suja, afirma o Relatório da ONU (ANA, 2019).

Outra pesquisa, reafirma a desigualdade entre países, com registro de doenças infecciosas transmissíveis e acusa como causa mortis de 50\%, metade dos motivos de morte, nos países de baixa renda. Doenças infecciosas, que matam mais que qualquer doença, estão inter-relacionadas à precariedade das moradias, à insalubridade dos entornos e saneamento básico inadequado, em oposição aos países de alta renda, onde essa causa é de apenas 7\% das mortes (OMS, 2018) pois esses, contam com tratamento de esgoto, espaços livres, vegetação, moradias bem ventiladas e ensolaradas, tratamento urbanístico e saneamento básico diferenciado que confere o direito à cidade para poucos. 
Essa pesquisa ratifica a espantosa informação, trazida pelas Nações Unidas (NU, 2019) que divulgam as deficiências mundiais sobre água potável e instalações sanitárias:

- 2,1 bilhões de pessoas vivem sem água potável em casa;

- 4,5 bilhões de pessoas, ou seis entre dez, não têm instalações sanitárias geridas de forma segura.

O aumento das precariedades é proporcional ao aumento das populações. Sabe-se que o processo de industrialização e urbanização mudou o mundo e contribui para conurbações ${ }^{1}$ urbanas além do surgimento de grandes e megacidades em função do crescimento rápido e em tão alto grau, da população urbana, que em 1960 , apenas $25 \%$ da população mundial vivia nas cidades (SANTOS, 2012) e no início do século XXI, após meio século, mais que dobrou a população urbana, que chega a $55 \%$. Se continuar nesse ritmo crescente, até 2050 as cidades abrigarão 70\% da população mundial. Nos países em desenvolvimento esse aumento é, ainda, maior. Na América Latina, principalmente no cone sul, o percentual já supera os 80\% (ONU, 2019). O Brasil alcança 84,72\% (IBGE, 2015) com grandes assentamentos de favelas, onde vive $6 \%$ da população (MEIRELLES \& ATHAYDE, 2014). Segundo IBGE (2020) existem 5.127.747 domicílios no país, assentados em aglomerados subnormais, ou seja, com carência de serviços públicos essenciais e localizados em áreas com restrição à ocupação. Se contar, somente quatro pessoas por habitação, ter-se-á aproximadamente vinte milhões de pessoas. Como a população brasileira é de 211 milhões de habitantes (IBGE, 2020), significa que 10\% dos brasileiros vive em habitações subnormais.

Dentre tantas publicações sobre habitações e modelos de urbanização, relacionados a infecção e contágio, aponta-se o Hidden Cities - "Cidades ocultas: desmascarando e superando as iniquidades em saúde nos ambientes urbanos", que em vista do contingente habitacional do planeta, expõe a saúde global e aponta a necessidade de infraestruturas e serviços como os problemas mais consideráveis do século XXI (WHO, UN-HABITAT, 2010). O documento reafirma a carência e deficiência de saneamento básico ocultas nos subterrâneos da visão capitalista das cidades. Como no pensamento de Lefebvre (1999, p.142) a cidade é "o pano de fundo da sociedade burguesa" e como tal, manifesta suas contradições como as segregações.

\footnotetext{
${ }^{1}$ Crescimento de duas ou mais cidades que se expandem e se unem, uma a outra, no espaço geográfico, de maneira a formar uma mancha urbana que ultrapassa os limites territoriais de cada uma e não se percebe onde começa uma e onde termina outra.
} 
O Relatório das Cidades Mundiais 2016 demonstra inequivocamente a insustentabilidade do atual modelo de urbanização global, em muitos aspectos como desigualdade, mudança climática, informalidade, insegurança e as formas insustentáveis de expansão urbana, indicando a necessidade de mudança de atitudes e consciência para responder melhor aos desafios desse tempo (UN-HABITAT, 2016).

Os dados pontuais de água potável e esgotamento sanitário citados, retratam o quadro mundial da alta possibilidade de doenças infecciosas que confirmam infraestrutura e habitação ineficientes de uma sociedade fragmentada, desconectada da complexidade da vida e do senso de coletividade.

Identifica-se, dessa forma, a supremacia do direito individual frente aos interesses e direitos da sociedade. Esses dados, confirmam a corrente filosófica e a política do individualismo (HOBBES, 2015; SMITH, 1983) e seguem no rastro do modelo de urbanização, como abaixo citado.

Neiderud (2015), indica a alta densidade populacional e o contato próximo entre as pessoas, nas áreas urbanas como potenciais pontos quentes para a rápida disseminação de doenças infecciosas.

Importante lembrar que o modelo contemporâneo de cidade ainda se desenvolve baseado nos princípios do movimento higienista que surgiu no século XVIII que ressurge no século XIX com a era industrial (FRANCO, 2008). O modelo de cidade polarizada, com apenas um centro, dividida em zonas de usos do solo específicas, como as zonas residenciais exclusivas, desconectadas, distantes dos centros urbanos, aglomera e obriga os deslocamentos diários, de pessoas de alta, média e de baixa classe social, como um pêndulo que vai e volta, para compras, saúde, trabalho, estudo e moradia, o que acelera a dispersão do contágio.

No movimento higienista, especialistas ativam ações de gestão e planejamento para melhorar habitações e saneamento e alteram o desenho das cidades industriais, que naquele momento espalham cólera e febre tifoide devido à alta densidade habitacional e canalizações de esgoto a céu aberto, detritos e resíduos tóxicos industriais que se amontoam ao lado das moradias. Esse modelo alimenta a noção de conforto e embelezamento (FRANCO, 2000; HOAY, 2000; ROGERS, 2001; SOUZA, 2001).

Essa característica segregacionista, que aglomera e necessita de transporte pendular, é desaprovada frente à predisposição de contágio da Covid-19. Que produção de cidade contemporânea é essa que usa o mesmo princípio das cidades do século XIX, que deixa de lado o ser, o aspecto cultural e comunitário e ignora os impactos ambientais e sociais? O modelo urbano em questão tende às certezas, à convicção, a não contestação, como se não houvesse alternativa para um maior e melhor acerto. 
A cidade é um bem comum cuja parcialidade de uso a tragédia dos comuns denuncia (como se verá no tópico seguinte), pois a cidade contemporânea está baseada em preceitos individualistas e contém diretrizes para se pensar que o individual está acima do coletivo. Maricato (2020) cita que a cidade é um negócio e é conduzida por interesses imobiliários. Esses interesses individuais são maiores que os interesses sociais e coletivos. Os agentes políticos não conseguem impor limites, mesmo tendo leis urbanas brasileiras citadas mundialmente pelo avanço da democratização do planejamento urbano e da governança, como o Estatuto da Cidade e a própria Constituição Federal.

Diante do aparecimento da Covid-19, especialistas indicam (ANDRIOTI, 2020) o modelo de cidade compacta, estudada e referenciada por Rogers (2001) e Rueda (2000) que aparece como sugestão para uma cidade sustentável, numa contribuição sistemática para sua operacionalização, em De Oliveira e Milioli (2014).

Oposto das cidades atuais, densas e compartimentadas em zonas de uso, a cidade compacta tem multifunção ou zoneamento misto e vários centros produtivos, o que desobriga o morador a se locomover diariamente, melhora a qualidade do ar, diminui a aglomeração de pessoas (ROGERS, 2001) e facilita o distanciamento de dois metros, o que dificulta contágios. Além disso, instiga o caminhar e andar de bicicleta, que é saudável, prazeroso e melhora a sociabilidade. Ademais, aumenta a taxa de permeabilidade, liberando e melhorando o fluxo hidrológico natural. Isso melhora a saúde do habitante.

Os dados sobre água e esgotamento sanitário e estudos sobre carência e ineficiência de habitações e modelos de urbanização os quais se relacionam à infecção e contágio, acima citados, confirmam que os cientistas esperavam a pandemia, particularmente pela negligência dos Governos e sistemas públicos de saúde que foram avisados sobre tais dados e estudos. Tanto o alto número dos assentamentos subnormais, no Brasil, como outras situações mundiais apontam a falta generalizada de sensibilidade da gestão pública quanto à precariedade das habitações e seus entornos, à carência ou ineficiência de espaços públicos e aos modelos de urbanização, que evidenciam interconexões com doenças infecciosas e com a saúde global.

Documentos direcionados a líderes municipais e formuladores de políticas, pesquisas e dados de interesse de gestores e técnicos das cidades, pelo visto, têm pouca percepção. A falta de vontade política está latente, se analisado a partir do combate à mudança climática, aos impactos à biodiversidade, à miséria e ao direito à água. Maturana e Varela (2001) ensinam que cada um entende a partir de suas vivências e Pregogine (2009) lembra que as decisões tomadas dependem das perspectivas para o futuro, conforme ver-se-á no próximo capítulo. 
Petrella dá um grito de alerta para a população reagir: "em 2050 [...] os habitantes de aproximadamente 300 a 482 cidades mais populosas do mundo não terão acesso à água potável e aos serviços higiênico-sanitários de base. Trata-se de um cenário absurdo. Nossas sociedades não podem deixar de reagir com força" (PETRELLA, 2019, tese 24).

Fica clara a importância da participação popular na gestão e no planejamento urbano, pois essa traz consigo as reivindicações da população que podem chegar às políticas públicas, o que certamente melhora a vida da maioria das pessoas e do planeta.

Apesar das leis que regulamentam as questões ambientais dentro da cidade, tanto normas gerais, como leis municipais, percebe-se que a população, técnicos e poder público não as tornam eficazes em função das lacunas da lei e interpretações jurídicas discriminam o meio ambiente, desconectando-o da cidade e das pessoas, ignorando o todo interdependente.

Um dos legados da pandemia deverá ser a velocidade da transição, para se realizar, logo, uma mudança radical no pensar e no perceber a necessidade de transformar esse sistema falido, as atitudes coletivas insustentáveis e, consequentemente, as políticas públicas.

A transmutação de valores que a Covid-19 visibiliza, favorece uma nova era, já esperada por Morin (2011), com conscientização individual e coletiva. Esses valores interconectados à inteligência da Natureza pode presentear qualidade de vida e revelar a complexidade que é peculiar, com consciência planetária. Afinal, vive-se no mesmo planeta. "Uma consciência planetária que ultrapassa as consciências internacionalistas das últimas décadas está começando a emergir com a ideia de uma Terra-Pátria da qual somos filhos. Passa-se, assim, de um universal abstrato a um universal concreto, porque se trata da Terra" (MORIN, 2011, p.30).

Além das reflexões sobre as cidades quanto a necessidade de repensar o modelo de urbanização, aumentar e melhorar os espaços públicos e da mudança para a ação individual pelo bem comum, essa parada mundial dá um alento à Terra que diminui o impacto ambiental, o gasto de energia e o consumo, e descongestiona o trânsito pois congrega as pessoas virtualmente. Além disso, as soluções estão aí, estudadas e conhecidas para serem usadas, as mesmas pensadas por visionários de uma cidade sustentável e de um planeta onde todos possam viver bem, como por exemplo o que consta no conteúdo da Carta da Terra, há 20 anos.

A seguir algumas teorias e pesquisas que contribuem com gestores públicos na mudança de paradigma e auxiliam na construção de cidades que supõem saúde e qualidade de vida para os habitantes. 


\section{BASE TEÓRICA PARA A MUDANÇA DE PARADIGMA}

- O pensamento Complexo de Edgar Morin e o Ecossistema Urbano

A base teórica do pensamento complexo aplicada ao ecossistema urbano (MORIN, 1984) denuncia o limite do pensamento cartesiano e fragmentado, cujo comportamento as cidades refletem.

O pensamento complexo (MORIN, 2005a) é multidimensional e diverso. "A palavra complexo é tirada do latim complexus e complecti que significam 'o que é tecido em conjunto' (complexus) ou 'o que contém elementos diferentes' (complecti). A complexidade não é a completude." (FORTIN, 2005, p. 33).

Entendendo como as coisas não são, pode-se evoluir para a complexidade do todo. Esse é o método de Morin (2005a) cujo objetivo é auxiliar o ser humano a reaprender a pensar. Ele trabalha outros conceitos científicos ${ }^{2}$ no campo do pensamento, da imaginação e da ação. Com sua concepção de "homo complexus", ele remete à tolerância e à aceitação como humanidade imperfeita.

O termo "complexo" (MORIN, 2005a) veio para explicar a complexidade da sociedade, do pensamento, das relações e da vida, mesmo sendo crítico do conceito de complexidade ${ }^{3}$ nas ciências exatas. $\mathrm{O}$ autor enfatiza que o desenvolvimento da complexidade ultrapassa a visão de sistemas. $\mathrm{O}$ que ele quer dizer é que os seres vivos, que ele denomina de seres-máquina, sem deixarem de ser sistemas, são muito mais do que sistemas. "O ser, a existência, a vida, ultrapassam em tudo a noção de sistema; eles a envolvem, mas não são envolvidos por ela" (MORIN, 2005c, p. 189), portanto, reduzir a vida à noção de sistema, é fazer da própria vida um conceito esqueleto, necessário ao sistema, mas sem carne, sem cérebro, sem vida (MORIN, 2005b, p. 189).

Além da complexidade, Morin (1984) é um expoente do conceito de ecossistema urbano, quando diz que o caráter ecossistêmico de um aglomerado urbano é fornecido pela diversidade e multidimensionalidade de sistemas como as organizações e instituições políticas, sociais e culturais, além dos artefatos, máquinas e produtos reagindo de maneira interconectada de relações e de interações numa unidade ecológica. A civilização urbana instala o ecossistema urbano no espaço natural com os elementos que o compõe - os indivíduos, os grupos, as empresas e as instituições, numa

2 O princípio da Incerteza, de Heisenberg, a teoria da relatividade, de Einstein, a teoria dos sistemas, de Bertalanffy e Maturana e Varela, os campos morfogenéticos, de Sheldrake, a teoria do todo de Hawking estão dentre esses novos paradigmas científicos citados. (RUSCHEL, 2018)

3 Também conhecida como "dinâmica não linear" ou "teoria dos sistemas não lineares" ou ainda, "teoria dos sistemas dinâmicos" (CAPRA; LUISI, 2014, p. 135). 
relação aberta e interdependente, em coprodução circular e multiplicidade de relações entre indivíduos, sociedade, economia e ecologia que marcam a complexidade e a autonomia estabelecida com o ecossistema. Quanto mais rico em espécies maiores são os mecanismos de equilíbrio. A "totalidade de relações e de interações no seio de uma unidade ecológica" marca a existência do aglomerado urbano onde pode haver desordem múltipla e ampla, se o ambiente for perturbado (MORIN, 1984, p.98), por consumo, inundações, epidemias, poluição, congestionamentos, alta densidade demográfica, etc.

O autor e ecólogos naturalistas afirmam que o ecossistema urbano é vitalmente dependente do ecossistema natural para sua nutrição energética do qual extrai elementos e alimentos para sua sobrevivência e seu desenvolvimento. Isto confirma o caráter ecológico do meio urbano.

O pensamento complexo, além de incluir a filosofia, é fruto de uma necessidade de reaprender a pensar, que deriva das novas descobertas científicas. Em suas próprias palavras, Morin menciona:

Compreendi quanto era inútil provar só ao nível do fenômeno: a sua mensagem é rapidamente reabsorvida por mecanismos de esquecimento que dependem da autodefesa do sistema de ideias ameaçado. Eu compreendi que era inútil apenas contestar: apenas uma nova fundação pode arruinar a antiga. É por isso que eu penso que a questão crucial é a de um princípio organizador do conhecimento, e o que é vital hoje em dia não é apenas aprender, não é apenas desaprender, mas reorganizar nosso sistema mental para reaprender a aprender (MORIN, 2005b, p. 35).

Dessa mesma forma são as cidades contemporâneas, que necessitam ser requalificadas e reorganizadas. É inútil esquecermos as estruturas físicas ameaçadas, é inútil apenas contestar, pois é impossível recomeçar do zero. Precisa-se partir do existente e repensar, recompor, reconstituir a sociedade e suas estruturas.

O pensamento complexo propõe três princípios para superar o pensamento atual. O primeiro deles é o Princípio Recursivo, no qual o produto e o efeito são necessários à produção e a causação (FORTIN, 2006, p. 62), "qualquer processo cujo os estados ou efeitos finais produzem os estados iniciais ou as causas iniciais" (MORIN, 2005h, p. 108); o segundo é o Princípio Dialógico, que liga termos antagônicos e contraditórios para conhecer a realidade (MORIN, 2005h, p. 108); e o terceiro é o Princípio Hologramático ou Holonômico, que constata que não só a parte está no todo, mas o todo também está na parte (MORIN, 2005, p. 108).

Acredita-se que um dos papeis das ciências sociais e da educação é introduzir a toda a população outra forma de enxergar o mundo a partir dessas descobertas. No entanto, faz-se necessário repensar também as estruturas do direito, para que se consiga, a partir de regras e 
pensamentos mais holísticos, transformar a relação de conflito que dá as bases do direito, para uma relação onde o direito contribua para a transformação social. As cidades estão neste contexto e precisam também ser repensadas para uma vida mais saudável e com maior qualidade de vida.

O método científico clássico obriga os seres humanos a expulsarem a noção de sujeito até de nós mesmos. Isso, no entanto, biologicamente é impossível, pois a subjetividade é comum a todas as criaturas, humanas ou não (MORIN, 2005a, p. 337).

Às ciências sociais caberia uma nova forma de agir, dentro de uma nova visão de mundo. $E$ ao Direito, caberia uma adaptação e uma revolução na maneira como se legisla e a maneira com que se aplica a norma. Não se trata de uma adaptação ao que fazer e sim ao como fazer para dirimir de fato os conflitos existentes. No caso de uma cidade, o 'como fazer' se aplica ao urbanismo do qual resultam normas urbanísticas que compõem um plano. O planejamento urbano trabalha recursivamente onde o produto é a cidade e o efeito seria a produção da qualidade de vida e da saúde dos habitantes em processo cíclico e interativo, segundo o Princípio Dialógico, de adaptação e de avaliação dos planos, pela comunidade.

Por isso, é necessário tratar com complexidade os problemas complexos da cidade (JACOBS, 2001; CAPRA, 2006b). Nesse contexto, a pandemia aclarou como a saúde está no planejamento urbano o qual atravessa todas as esferas de uma cidade, ou seja, sua multidimensionalidade e diversidade. Portanto, precisa da visão complexa para seu tratamento.

Em síntese, Edgar Morin procura um método que reconheça a riqueza e a multidimensionalidade das coisas. Ele procura elaborar uma estratégia capaz de unir os conhecimentos desligados pelo método da simplificação. Assim, poder-se-ia criar a possibilidade de rearticular as ciências naturais - exatas e biológicas - nas ciências antropossociais, permitindo um pensamento que resulte de ações não mutilantes (FORTIN, 2005, p. 26 - 27).

O planejamento urbano eficiente e sustentável necessita dessa rearticulação das ciências naturais nas ciências antropossociais. Fica, deste modo, confirmada a visão complexa do planejamento urbano que precisa de um método que reconheça a riqueza e a multidimensionalidade das coisas e a interconexão das partes no todo, onde o todo (a cidade) está nas partes (bairros) e as partes estão no todo. Ou seja, é necessário tratar o esgoto, a água, os rios e suas margens, em toda a cidade, para todos. Pois, as questões sociais e culturais estão interconectadas com os problemas do meio ambiente, e da economia, e esses interligados diretamente às questões de habitação, saúde, biodiversidade e mudanças climáticas, que por sua vez estão ligados à água, saneamento, energia, segurança, miséria, analfabetismo, escola, etc. que atingem a todos os habitantes. 
$\mathrm{Na}$ pandemia pode-se perceber que é impossível separar o todo das partes, mesmo segregando, é impossível separar o individualismo do coletivo. Inexiste anteparo que separe um contágio!

- A Escola de Santiago e a criação da subjetividade para a racionalidade coletiva e ecológica

Acredita-se que as descobertas científicas feitas pela Escola de Santiago (biologia da cognição) trazem a prova de que a estrutura formada pelo direito para proteção das cidades é limitada e precisa ser repensada.

Conforme a biologia da cognição, os seres vivos são sistemas autônomos, determinando os seus comportamentos a partir de seus próprios referenciais. A partir da influência do meio, eles veem o mundo e agem de acordo com suas próprias experiências. A descoberta da Escola de Santiago vem revolucionar a forma como se vê o outro: cada ser tem a sua própria percepção e não há como mudar a percepção do outro. Cada um age a partir daquilo que conhece. Portanto tentar mudar a ação de qualquer outro ser humano é impossível. Tende-se a viver num mundo de certezas, de solidez perceptiva não contestada, em que as conviç̧ões provam que as coisas são somente como cada um as vê e não existe alternativa para aquilo que parece certo ao outro. Essa é a situação cotidiana, a condição cultural, o modo habitual de ser humano (MATURANA; VARELA, 2001, p. 22).

As experiências estão calcadas numa estrutura mutável, ou seja, é impossível visualizar a realidade, a menos que se faça isso a partir das próprias experiências. Essa afirmativa está afiançada em Ilya Prigogine (2009, p.11) quando diz que as "decisões humanas dependem das lembranças do passado e das expectativas do futuro". Sendo assim, Maturana e Varela (2001, p. 28) afirmam que "não vemos o espaço do mundo, mas vivemos o nosso campo visual; não vemos as cores do mundo, vivemos nosso espaço cromático".

Desta maneira, passa-se a entender a necessidade de reflexão sobre aquilo que se conhece. Até então, a cultura ocidental ligava o processo 'do conhecer' com o processo de ação, de representação de uma realidade comum. Como se conhecer algo fosse apenas a partir de uma ação própria, separando o sujeito que busca conhecer, do objeto a ser conhecido.

A teoria sistêmica identifica o processo da vida com o processo de conhecer, que é mais que pensar e envolve percepção, emoção e ação, que segundo Capra (2006, p. 144), talvez seja "o aspecto mais revolucionário e mais instigante dessa teoria, uma vez que ela promete, finalmente, superar a divisão cartesiana entre mente e matéria". 
A biologia do conhecimento rompe com a ideia de captação de um mundo objetivo, fora do sujeito, independente da ação do sujeito que conhece e que se constitui ao atuar. A ideia de entrada e saída são abolidas. O sistema percebe a partir das perturbações que sofre do meio (PELLANDA, 2009, p. 22 - 23).

A dedução é que os seres vivos se caracterizam por produzirem de modo contínuo a si próprios. Este fenômeno de organização é conceituado como autopoiese e abre a possibilidade de identificar os limites no direito e, ao mesmo tempo, o limite dos modelos urbanos utilizados até os dias atuais.

Nesse sentido, a comunicação como algo que o transmissor entrega para o receptor, de fato, não existe. "Cada pessoa diz o que diz e ouve o que ouve segundo a sua própria determinação estrutural" (MATURANA; VARELA, 2001, p. 218), segundo a sua própria experiência no mundo: fazer é conhecer e conhecer é fazer.

Tomando a ideia de abolir entradas e saídas (PELLANDA, 2009) no urbanismo, pode-se aplicar o metabolismo circular (GIRARDET, 2007; 2010). Uma cidade, tratada como um ecossistema urbano poderá se tornar mais sustentável (DE OLIVEIRA, 2018) quando o descarte de um organismo seja usado por outro, de forma circular, em fluxo constante, sem sobra de resíduos. Esse fenômeno funciona num sistema complexo, seja numa cadeia alimentar ou numa floresta (CAPRA, 2006) ou ainda, numa cidade.

Assim, ao se utilizar de um metabolismo circular, uma cidade poderá diminuir as entradas de materiais e energias e minimizar as saídas de poluição, resíduos orgânicos e inorgânicos (GIRARDET, 2007; 2010), que rompe a ideia de entrada e saída da biologia do conhecimento (PELLANDA, 2009).

Se o ser e o fazer nos seres vivos são inseparáveis (CAPRA, 2006; MATURANA; VARELA, 2001) a conclusão é que não há separação entre produtor e produto. Essa visão muda radicalmente a forma como o sujeito se vê no mundo.

Portanto, a experiência da certeza é um fenômeno individual, cego, em relação ao ato cognitivo do outro. Deste modo, todo o conhecer passa pelas experiências e não existe a transmissão da comunicação. A informação não é determinada pelo agente perturbador que comunica, mas pelo agente receptor da informação.

Nesse ponto faz-se importante diferenciar a corrente filosófica e política do individualismo, que prima pela supremacia do direito individual frente aos interesses e direitos da sociedade (HOBBES, 2015; SMITH, 1983). Sem dúvida, quando a luta por preceitos individualistas surgiu, tal fato justificava-se, pois, os sujeitos não tinham liberdade e ficavam à mercê de senhores feudais e da igreja. No entanto, a humanidade e o pensamento jurídico ainda hoje se desenvolvem baseada nesses preceitos, sob o efeito manada. 
Tais preceitos individualistas intensificaram-se com o que Guatarri (1990) chamou de produção de subjetividades. Ou seja, com os meios de condicionamento de massa, sabendo-se das bases teóricas advindas da Escola de Santiago, cria-se, através dos meios de comunicação de massa e do marketing, necessidades que estimulam o consumo, o capitalismo e a cultura do bem-estar social, e não somente deixam de lado o ser e o aspecto cultural e comunitário, como ignoram os impactos ambientais.

As denúncias sobre a ação antropocêntrica e as irresponsabilidades sobre o esgotamento dos recursos naturais iniciam uma inquietação mundial em 1962, quando do lançamento do livro Primavera Silenciosa, de Raquel Carson (2010), que provoca a comunidade internacional de maneira a iniciar a história do movimento ecológico, com o relatório 'Os limites do Crescimento' (MEADOWS, 1973), que critica o modelo que, hoje, sabe-se é gerador de problemas sistêmicos.

Conhecendo os estudos da Escola de Santiago, pode-se criar subjetividades positivas para o meio ambiente e para a cidade. Isto requer que as pessoas internalizem subjetividades positivas para o ambiente e passem a mudar seu ponto de vista e os seus padrões de comportamento a partir dessas vivências. $\mathrm{O}$ que isso poderia auxiliar numa cidade sustentável que traga saúde, qualidade de vida e justiça para os habitantes!

A tragédia dos comuns denuncia ações baseadas em preceitos individualistas e, mesmo que tenha limitações, sem dúvida traz as primeiras diretrizes para se pensar o coletivo acima do individual.

- A Tragédia dos Comuns e a pandemia da Covid-19

O tema dos comuns denuncia a sobre-exploração de recursos naturais de uso comum e surge com o ecologista Garrett Hardin em 1968. O artigo de Hardin tem uma importância fundamental, pois vai além, e alerta para os limites do tecnicismo, dos perigos da racionalidade individual frente a uma racionalidade coletiva, além de demonstrar os riscos ambientais e sociais de uma superexploração da Terra. O autor (p. 1243) chama atenção para os "problemas técnicos sem solução" e enfatiza tal teoria com o problema populacional, mencionando que as pessoas normalmente se angustiam com o problema da superpopulação, mas acreditam que uma solução técnica resolverá o problema e elas não precisarão renunciar dos privilégios que desfrutam. A solução técnica seria aquela que requer mudança apenas nas ciências naturais, exigindo pouco ou nada nos valores humanos e na ideia de moralidade. Essa afirmação vai ao encontro do Pensamento Complexo e da Escola de Santiago. 
A reflexão está nos pontos positivos e negativos de agir baseado unicamente em uma racionalidade individual e sobreposta à racionalidade coletiva. Para levar os leitores a pensarem sobre a racionalidade, o autor cita a Riqueza das Nações e a "Mão Invisível" de Adam Smith. A ideia central é que não há uma entidade para regular interesses comuns do mercado que regre interesses da comunidade, por isso o agir dos indivíduos parece resultar numa perfeita ordem, como se uma "mão invisível" orientasse toda a economia. Em outras palavras, para uma ordem de mercado, todos acabam agindo conforme o melhor para o seu crescimento individual, com racionalidade individual. Esta ação acaba por ser guiada por uma "mão invisível" que ordena o mercado (SMITH, 1983).

Para mostrar a falha deste sistema, Hardin (1968) baseou-se em um matemático chamado William Forster Llyd, que escreve em 1833 sobre os problemas populacionais e sobre a tragédia dos comuns. Ilustra tal situação imaginando um pasto que é aberto para todos. Neste caso, ele fala de um terreno de livre acesso a todos.

Os vaqueiros que se utilizam desse pasto, se pensarem de forma racional - conforme a mão invisível de Smith - provavelmente colocarão mais gado para aumentar o seu rebanho e aí maximizar seus lucros. No entanto, tal atitude tem uma consequência positiva para o indivíduo que durante algum tempo ganhará mais, e também negativa, já que os danos causados pelo sobrepastoreio serão compartilhados por todos (HARDIN, 1968).

Cada pastor que utiliza o terreno conclui racionalmente que o mais adequado é adicionar mais e mais gado no seu rebanho. A tragédia se encontra neste ponto, pois o bem é comum e utilizado com uma racionalidade individual que acaba com uma área que é limitada e é de todos. Ou seja, os benefícios são particulares e os problemas são coletivos.

Como exemplo, vale destacar a mineração de carvão na região carbonífera catarinense que outorgou a Criciúma o título de capital brasileira do carvão e por consequência, em décadas passadas, a histórica 14a área crítica poluída do país ${ }^{4}$ (MILIOLI, 1999). Nesse contexto, os mineradores enriquecem individualmente e poluem ar, solo e rios que são bens comuns, produzindo por extensão um legado de passivos ambientais e também um conjunto de externalidades socioambientais.

\footnotetext{
${ }^{4}$ A região carbonífera catarinense (e os Municípios da AMREC - Associação dos Municípios da Região Carbonífera), está situada no sul de Santa Catarina, possui 12 municípios de distintas características culturais e uma população de aproximadamente 438.500 habitantes (IBGE, 2019).
} 
Hardin (1968, p.1244) conclui afirmando que "a liberdade em relação a recursos comuns gera a ruína de todos". Sem dúvida, há a supremacia do direito social frente ao direito individual. No entanto, como cada ser no mundo tem suas próprias percepções (MATURANA; VARELA, 2001), precisa-se sair da ilusão que é possível mudar o outro.

Neste ponto, percebe-se a necessidade recursiva da figura do Estado. Este vem para determinar medidas que seriam fundamentais para a harmonia geral de toda a coletividade. Se os indivíduos não conseguem fazer a sua parte, por estarem como massa de manobra de interesses maiores, vem o Estado, como um ente superior, para impor alguns limites à verdade subjetiva e ao direito individual.

No entanto, a figura do Estado se encontra também em crise. Precisa-se construir outra forma de 'ser' no mundo, pois a forma catastrófica desse sistema torna as pessoas individualistas, consumistas e injustas social e ambientalmente, o que poderá eliminar a humanidade da face da Terra. Morin (2011, p.13) afirma que "todos os processos atuais conduzem à catástrofe", contudo o improvável permanece possível e poderá ser substituído pelo provável. "É por isso que não devemos mais continuar na rota do 'desenvolvimento'. Precisamos mudar o caminho, precisamos de um novo começo" (MORIN, 2011, p. 15).

Morin antevê esse "novo começo". O movimento ambientalista e todas as demais discussões mundiais recorrentes, até hoje, alertam para tentar amenizar a crise da humanidade. Essa crise capitalista global, portanto, que produziu a Covid-19 se arrasta há meio século. A pandemia, apenas, evidenciou as desigualdades sociais e os problemas estruturais das sociedades do mundo e instalou um processo de transição nesse momento especial como civilização. Essa pandemia aponta que não há barreiras, nem muros, que possam separar o individualismo do coletivo.

Ela traz consigo uma nova ordem mundial, capaz de mudar o paradigma, que poderá servir para a construção de outra forma de vida humana na Terra que se confia, seja para melhorar, para fortalecer outra consciência global. Como disse Morin (2011, p.15), a "metamorfose que se tornou algo vital".

Como existe o provável, existe também a dúvida e surge a questão se haverá, efetivamente, um processo de aprendizado coletivo pós-pandemia. Ninguém sabe o que virá. Crise é chance de mudar, embora Morin (2020) lembra que uma crise poderá trazer também, regresso. Esse é o perigo que se incorre, pois, a história conta que uma mudança é boa para uns e desastrosa para outros. Se piorar não terá valido à pena.

Há possibilidade, no pós-pandemia, dos ricos ficarem mais ricos e maior decadência dos pobres o que a Oxfam (2020) confirma ocorrência na América Latina, durante a pandemia, em relatório de 27 de julho de 2020. Isso poderá dissimular a atenção de outras emergências, como as mudanças climáticas 
ou o direito à água ${ }^{5}$. É incerto afirmar o que virá, mas esse é um novo tempo, que se deseja seja um tempo de consciência coletiva para um mundo mais solidário.

Os adeptos da cidade ecológica e sustentável, percebem a necessidade e sonham com mudança de pensamento e atitudes. Mas como o ser humano não é capaz de visualizar a realidade sem vivenciála, que conforme Maturana e Varela (2001) só é possível mudar a partir da sua própria experiência, veio a Covid-19 para que todos pudessem ver a realidade tão desigual e perceber o quanto os impactos à Natureza afetam as pessoas e quão deprimente é a vida para tantos.

Nessa pandemia, a área social, da saúde, da cultura e da economia surpreendem cada uma a sua maneira, todo o sistema. Fizeram a civilização mundial refletir que é necessário entender, primeiro, qual o propósito de vida na Terra e que se precisa construir outro mundo pois esse sistema já não se sustenta mais. No entanto, o direito encontra-se paralisado. No Brasil, no contexto da pandemia, apesar de todas as catástrofes relacionadas às queimadas e às terras indígenas, nota-se poucas atitudes por parte dos governantes, do poder judiciário e da população. O sistema individualista deve dar lugar a uma consciência mais coletiva, para uma sociedade mais igualitária, mais respeitosa com a natureza e mais consciente dos seus limites. Cada um fazendo a sua parte, pelo bem comum, atingem as ações globalmente.

\section{CONSIDERAÇÕES SOBRE O DIREITO À CIDADE FRENTE À PANDEMIA DA COVID-19}

Estudou-se que o sujeito só conhece a partir de suas experiências, por isso a incapacidade de visualizar a realidade toma conta de cidadãos, técnicos, políticos e gestores, evidenciado pela Escola de Santiago (MATURANA; VARELA, 2001) e no pensamento complexo de MORIN (2005a, 2005b, 2005b, 2005c, 2005d, 2005e, 2005f, 2011) estudados no segundo tópico deste artigo. Essas teorias justificam o motivo pelo qual medidas preventivas não foram tomadas perante dados científicos e soluções expostos para os problemas e doenças, que já contagiaram e contagiarão o mundo.

Assim, a transmissão da comunicação de conhecimentos através da ciência, não existe para os formuladores de políticas que não tem vivência e, consequentemente, conhecimento de fato para perceber o problema, sem contar que sua perspectiva política é o voto. Como citado por Pellanda (2009, p. 23) "conhecer não diz respeito somente ao intelecto, mas a todas as dimensões da nossa vida" e a dimensão da maioria dos políticos é o voto. Em razão de vivenciar os problemas in loco, a dimensão da

\footnotetext{
${ }^{5}$ A pandemia deixou passar incólume o Marco Regulatório do Saneamento, aprovado em 24 junho 2020, que induz à privatização da água (CF, 2020).
} 
população são os fatos reais, os acontecimentos. Vem dessa circunstância, da experiência da população local, que há necessidade da participação do povo nas decisões locais.

Viu-se também, que o sistema capitalista contribui para a desigualdade social e impactos ambientais. A Covid-19 parou o sistema e desafia os tomadores de decisão política, os técnicos e os intelectuais do planeta a melhorarem a situação das cidades, com relação à precariedade e carência das habitações, à necessidade de espaços públicos suficientes e eficientes e ao saneamento e água para todos, entendidos aqui como o direito à cidade. Mesmo porque a Constituição Federal supõe a construção de cidades mais justas com acesso igualitário à moradia e espaços públicos eficientes e saudáveis.

Ressalta-se que é ilusório achar que tudo mudará imediatamente. As mudanças de ação acontecerão paulatinamente. O que se espera de imediato é a percepção das desigualdades e a conscientização da ação individual em prol do coletivo.

O Direito à Cidade é um direito humano coletivo, é um compromisso ético e político de defesa de um bem comum essencial a uma vida plena e digna. Nesse sentido, planejamento urbano aliado ao Direito à Cidade ao pode ajudar, com normas que modifiquem a forma como se estruturam as cidades, bem como trazendo maior valorização para o ambiente construído e natural. Dentre outras políticas públicas, podem servir de exemplo para normas jurídicas urbanas e sanitários, as abaixo listadas:

a. Reabilitação habitacional como fator preponderante na relação com a saúde das pessoas: Para diminuir a proliferação de vetores de transmissão, a cidade deve ter habitação arejada em tamanho proporcional ao número de habitantes e instalações sanitárias adequadas. Como exemplo o CAU.RS Conselho de Arquitetura e Urbanismo, do Rio Grande do Sul, lançou em 20/05/2020, o projeto 'Nenhuma Casa Sem Banheiro', através do programa ATHIS ${ }^{6}$.

b. Criação de política habitacional, eficiente na produção da cidade: Para ter direito à cidade, precisa ter direito à moradia. O programa Minha Casa Minha Vida - MCMV produziu 6,75 milhões de unidades habitacionais no país, mas o deficit habitacional total em 2012, foi estimado em 5,244 milhões de domicílios (KRAUSE et al, 2014) e em 2015, 6.356.000 de habitações (ARANTES, 2020). Essa temática precisa ser repensada no Brasil, pois segundo o IPEA (2020) - Instituto de Pesquisa Econômica Aplicada a carência continua, em $14,9 \%$ do total de domicílios. Isto se dá ao fato da coabitação e da densidade demasiada, por habitação. Lembrando que além da carência, a ineficiência da habitação está

\footnotetext{
${ }^{6}$ ATHIS é uma Lei de Assistência Técnica para Habitação de Interesse Social (Lei Federal no 11.888/2008), criada pelo arquiteto e urbanista gaúcho Clóvis llgenfritz da Silva e prevê projetos e moradia digna para famílias de baixa renda.
} 
representada por ocupação de áreas de risco e sujeitas à inundação. A produção eficiente da cidade está relacionada à localização da habitação.

c. Requalificação da cidade: repensar a expansão das periferias visando uma 'Cidade Compacta'. Como visto no capítulo primeiro, a Covid-19 deixa relevante a necessidade de mudança do modelo de cidade esparramada. Sugere-se a compactação da cidade de modo a preencher, primeiro, os vazios urbanos, compartimentando as áreas já estruturadas; renovar Planos Diretores incentivando as multifunções e criação de centros produtivos, para assim, diminuir a necessidade de locomoção pendular, diária, e a aglomeração de pessoas nos centros urbanos, facilitando o distanciamento de dois metros, dificultando o contágio; melhorar a mobilidade dos trabalhadores favorecendo o caminhar e o andar de bicicleta.

d. Conexão da cidade ao contingente habitacional urbano: Para ser saudável e feliz a cidade deve ter além de espaços públicos suficientes, espaços eficientes para caminhar, pedalar e permitir o encontro. Para ser saudável, "o espaço público deve ser vivo" e seguro (GEHL, 2013, p.63), pois quando as pessoas temem a rua elas a usam menos (JACOBS, 2001). Por conta do contingente habitacional dos países da América Latina e do alerta da Covid-19, a atenção aos espaços públicos e à qualidade da habitação, mais que relevante, está associada à ética do direito à cidade e a qualquer planejamento urbano que se pretenda sustentável e justo socialmente. Assim, torna-se o direito menos mecanicista e fragmentado e, recursivamente, com a sua ajuda, transforma-se, aos poucos, o pensamento e o condicionamento das pessoas sobre a cidade.

e. Melhoria da Mobilidade Urbana: A fim de efetivar as aconselháveis distâncias de segurança, toma-se o exemplo das alternativas sustentáveis da cidade de Barcelona - Espanha que, sem fazer obras, encontrou uma forma de diminuir a aglomeração perante a pandemia. Nessa cidade, ações simples, pontuais e baratas estão acontecendo para ampliar a largura das calçadas nas vias mais movimentadas, redesenhando literalmente esses espaços nas ruas, para os trabalhadores transitarem a pé. Novos corredores de bicicleta ou patinete e patins, também foram pintados para a ida e vinda ao trabalho. Paris, Milão e Nova York também já se movimentaram nesse sentido (COLS, 2020).

f. Incentivo à Pedagogia Urbana: A relação dos habitantes de uma comunidade com as decisões do planejamento urbano está na participação popular. Com a pandemia, fica cada vez mais importante a participação popular pela possibilidade de influenciar nas decisões políticas e na criação de políticas urbanas, pois está aí a capacidade de corrigir as desigualdades e tornar universal o acesso aos bens, serviços e infraestruturas locais. Além disso a formação acadêmica, referente à cidade, precisa ser mais crítica e interconectada às questões socioambientais, territoriais e políticas. Desta feita, Maricato (2020) 
traz uma inovação na ciência do Urbanismo, quando fala em "Pedagogia Urbana" - o cidadão, os profissionais e decisores políticos precisam de conhecimento sobre a cidade, sustentabilidade e cidadania para poderem reivindicar e decidir com visão coletiva e complexa.

g. Transformação da cidade em biofílica: A cidade muito além de ser sustentável pode ser biofílica, ou seja, por sua etimologia, contém a filosofia da natureza, além de muitos benefícios mentais e físicos ela compõem a estética do lugar pela presença marcante da vegetação e valores interconectados à inteligência da Natureza. Através de um planejamento urbano participativo, o indivíduo é estimulado a apreciar o cuidado com a natureza, desenvolvendo conexões emocionais com ela (NEWMAN e BATLLEY, 2013). Por isso, pode-se dizer que essa cidade, preconiza qualidade de vida e saúde aos habitantes, pois, como visto na introdução deste artigo, a população, gestores e técnicos entendem a interdependência ecológica entre os indivíduos e destes com a natureza de modo a agir e retroagir com o meio, cuidando-o e se envolvendo com a psicologia do lugar. Essa forte conexão, cuidado e experiência com a natureza, anima o cidadão a viver mais tempo fora de casa em caminhadas, ciclismo, observação de pássaros, observação do céu, jardinagem, que por sua vez aumenta o vínculo social e a resiliência da comunidade.

Santos (2020) alerta que os intelectuais devem estar atentos às necessidades e às aspirações dos cidadãos comuns e devem saber partir da necessidade atual para teorizar e melhorar de modo contínuo a própria realidade. Nesse sentido, Maturana e Varela (2001) dizem que 'o conhecer' é o fazer que é o conhecer. Dessa forma a "evolução individual e a evolução social condicionam-se mutuamente" (NICOLESCU, 2005, p.83), para organizar as comunidades e descobrir formas de estabelecer uma civilização ecológica, com qualidade de vida para cidadãos saudáveis. Esse é o desafio para uma evolução do modelo urbano que deve ser democrático e solidário no pós-Covid-19. Assim, a construção do conhecimento frente à questão urbana deve-se assentar na realidade cruel pela carência do Direito à Cidade. Para essa construção necessita-se mudança e subsequente formação de profissionais mais críticos e agentes políticos conscientes em aprendizado voltado ao pensamento complexo, o qual possibilita contribuir na formulação e implementação de políticas públicas urbanas sustentáveis necessárias às transformações. Por fim, a importância de uma pesquisa acadêmica chega ao seu ápice ao transformar o conhecimento e atingir a consciência de gestores que atuem nas realidades com esses novos conhecimentos.

Faz-se importante a interdisciplinaridade na gestão da cidade. Se a Arquitetura e Urbanismo, Direito e a Pedagogia da Cidade se unissem para trabalhar políticas públicas urbanas, se a formação acadêmica de arquitetos urbanistas fosse mais crítica e voltada para as soluções complexas, e a dos 
advogados levassem mais a sério o Direito Urbanístico talvez se implementasse, na prática, o dever fundamental à cidade.

Com o Estado de Direito e os Direitos Fundamentais, a sociedade abdicou dos deveres em prol dos direitos e esse fato ocasionou problemas de todos os níveis que se estendem para as cidades. "O direito de ter direitos principia - funda-se - no dever de ter deveres" (BARROS, 2003, p. 03). A conscientização traz a possiblidade de se efetivarem os deveres e por consequência, o direito à cidade.

Nesse sentido, acredita-se que as cidades são as comunidades contemporâneas e, por isso, para evitar a tragédia dos comuns é importante observar os deveres fundamentais e cumprir as regras de conduta para o bem de todos.

O paradigma complexo ensina que se faz necessário a interconexão entre tudo e todos. Portanto, todos os cidadãos, independente da classe social, tem o direito a uma cidade saudável, e com maior qualidade de vida, no entanto todos, também, devem agir com 'dever', conforme norma já disciplinada na Constituição Federal. Para garantir a equidade de todos os cidadãos faz-se necessário que o Estado assuma os seus deveres fundamentais, auxiliando as pessoas que vivem em lugares mais vulneráveis e que, consequentemente, tem menos garantia ao direito à cidade. Sendo assim, também os intelectuais, como ensina Santos (2020), precisam assumir atitudes mais sustentáveis e cumprir seus deveres fundamentais.

Dessa forma, Estado e cidadãos agindo em conjunto, cumprindo os deveres fundamentais, possibilitarão, no pós-pandemia, viver a cidade como um núcleo comunitário, onde cidadãos, espaço natural e espaço construído formem uma unidade complexa e se reconheçam todos como parte fundamental para a vida em harmonia, evitando assim a tragédia dos comuns.

\section{CONSIDERAÇÕES FINAIS}

O objetivo do artigo, de cunho interdisciplinar, teve como pauta a reflexão do direito à cidade, construída a partir do pensamento complexo de Morin, da Escola de Santiago e do alerta à tragédia dos comuns, sugerindo políticas públicas urbanísticas e estratégias jurídicas para cidades mais sustentáveis, baseadas no pensamento de Jacobs, 2001; Newman e Jennings, 2008; Gehl, 2013; Newman e Batlley, 2013 que possibilitem mais saúde e qualidade de vida às populações.

Para atingir o seu objetivo, explorou os itens a seguir: a) apontou alguns problemas das cidades; b) estudou as bases teóricas da presente pesquisa; c) trouxe preceitos e sugeriu soluções de uma cidade sustentável e ecológica. 
O primeiro tópico denunciou alguns obstáculos das cidades, como problemas sanitários e a carência e insegurança habitacional recorrentes, os impactos ambientais e o modelo urbano em vigor que acirram e propiciam a expansão do Corona vírus. Refletiu porque se continua a tratar as cidades de maneira a agravar a vida das pessoas e do planeta mesmo com o aumento populacional que muda estrutural e visivelmente as cidades. Apontou algumas ações que a tragédia dos comuns denuncia tais como problemas sanitários habitacionais e urbanos, falta de água potável, carência ou ineficiência de espaços públicos, expansão de cidades esparramadas pelo território do município e desconectadas do polo central, que exige o uso diário de transporte pendular para casa e o trabalho. O modelo de crescimento urbano além de produzir aglomeração, forma vulnerabilidade socioambiental e agrava a desigualdade entre países e cidades, entre bairros da mesma cidade e cria tanto, invisibilidade de pobres e miseráveis, refugiados e migrantes no submundo quanto a invisibilidade do direito à moradia.

O segundo tópico discorreu por teóricos e cientistas e demonstrou a importância do pensamento complexo e o ecossistema urbano de Edgar Morin nas relações, na vida, na sociedade e nas cidades contemporâneas; também investigou como as descobertas feitas pela Escola de Santiago revolucionaram a forma de ver o outro, em sua autopercepção. Por fim, como a pandemia da Covid-19 exteriorizou a tragédia dos comuns em relação aos impactos, aos recursos naturais e ao Direito à Cidade e como os adeptos da cidade sustentável, sonham com a mudança de pensamento e de atitudes.

O último tópico comparou a dificuldade no cumprimento das medidas em prol do coletivo, com os teóricos analisados, considerando o direito à cidade no pós-Covid-19. Apontou sugestões que podem solucionar na reorganização das cidades, tais como: a. Reabilitação habitacional como fator preponderante na relação com a saúde das pessoas e na qualidade de vida; b. Produção de política habitacional, eficiente na produção da cidade; c. Requalificação da cidade; d. Conexão da cidade ao contingente habitacional urbano; e. Melhoria da Mobilidade Urbana; f. Incentivo à Pedagogia Urbana; g. Transformação da cidade em biofílica.

Assim, confirma-se a hipótese do artigo de que a estrutura formada pelo Direito é insuficiente para auxiliar na construção de cidades que permitam qualidade de vida e saúde. Primeiro, porque faz-se necessário um rompimento com o paradigma mecanicista para se adentrar no paradigma complexo e isto leva tempo. Segundo, porque toda a estrutura jurídica baseia-se na fragmentação e na argumentação, o que demonstrou ser utópico e não corresponder com a realidade da vida. Precisa-se construir uma cidade com a participação da sociedade para que ela seja inclusiva e daí, então, construir estruturas de Direito, para que os benefícios sejam de longo prazo. A sociedade está doente e as cidades atualmente constituídas são recursivamente parte da causa, juntamente com um sistema jurídico, pois 
corroboram, da forma que estão constituídos, para a maximização dos conflitos e das doenças mentais e físicas dos indivíduos. Por outro lado, faz-se urgente a mudança de paradigma no auxílio da forma como os seres humanos se veem e veem o mundo.

A pandemia é transcendental, pois pode alavancar a mudança de consciência coletiva. Segundo Maturana e Varela (2001) as pessoas precisam vivenciar as realidades para poderem perceber. Neste caso, a pandemia veio evidenciar a realidade cruel das pessoas e das cidades, através das desigualdades brutais e do sistema falido mostrando quão irreal é o Direito à Cidade, para muitos.

Entende-se que as soluções já estão postas pelos estudiosos da cidade sustentável. Entendese, também, que há necessidade urgente de mudar, para solucionar problemas complexos, de forma complexa, mas é ilusão pensar em mudanças imediatas, elas virão paulatinamente. Mas virão!

É a "metamorfose que se tornou algo vital" (MORIN, 2011, p.15), por que da forma como está, o provável é não haver lugar para os humanos viverem, tampouco para os animais. O planeta precisa se regenerar!

\section{REFERÊNCIAS}

AMREC - Associação dos Municípios da Região Carbonífera. IBGE divulga as estimativas da população dos municípios para 2019.2 Disponível em: https://www.amrec.com.br/noticias/index/ver/codNoticia/571993/codMapaltem/42508 Acesso: 04 agosto 2020

ANA - Agência Nacional da Água. Água poluída mata mais que guerras. Disponível em: https://www.ana.gov.br/noticias-antigas/agua-poluada-mata-mais-que-guerras.2019-03-

14.4437851287 Acesso: 21 março 2019.

ARANTES, José Tadeu. Déficit habitacional é obstáculo para isolamento vertical, dizem pesquisadores. Agência FAPESP, em 02 de abril de 2020. Disponível em: https://agencia.fapesp.br/deficit-habitacionale-obstaculo-para-isolamento-vertical-dizem-pesquisadores/32874/ Acesso 15 outubro 2020.

ATHIS. Projeto Nenhuma Casa Sem Banheiro. CAU-RS Conselho de Arquitetura e Urbanismo, 2020. Disponível em: http://www.caurs.gov.br/athis/tag/nenhuma-casa-sem-banheiro/ Acesso 21 junho 2020.

BARROS, Sérgio Resende de. Direitos humanos: paradoxo da civilização. Belo Horizonte: Del Rey, 2003.

CHOAY, Françoise. O urbanismo: utopias e realidades, uma antologia. 5. ed. São Paulo: Perspectiva, 2000.

CAPRA, Fritjof. O ponto de mutação: a Ciência, a Sociedade e a Cultura emergente. São Paulo: Cultrix, 2006b. 
CAPRA, Fritjof. A Teia da Vida - uma compreensão científica dos sistemas vivos. Tradução Newton R. Eichemberg. São Paulo: Cultrix, 2006.

CAPRA, Fritjof. Pandemia é resposta biológica do planeta, diz físico Fritjof Capra. Folha de São Paulo. Disponível em: www1.folha.uol.com.br Acesso 11 agosto 2020.

CARSON, Raquel. Primavera silenciosa. São Paulo: Gaia, 2010.

CF- Congresso em Foco. Privatização da água ou melhora do serviço? Veja o que muda com a nova lei do saneamento. 25 junho 2020.2 Disponível em: https://congressoemfoco.uol.com.br/economia/privatizacao-da-agua-ou-melhora-do-servico-veja-oque-muda-com-a-nova-lei-do-saneamento/ Acesso 26 junho 2020.

COLS, Carles. Barcelona ampliará aceras y carriles bici para minimizar los contagios. Barcelona: El Periódico, 252020.200 abril 20 isponível https://www.elperiodico.com/es/barcelona/20200425/barcelona-ampliara-aceras-y-carriles-bici-paraminimizar-los-contagios-covid-7940149 Acesso em 27 abril 2020.

DE OLIVEIRA, Izes Regina \& MILIOLI, Geraldo. Sustentabilidade e Ecossistema Urbano: Relações entre a sociedade, o desenvolvimento e o meio ambiente nos municípios. Curitiba: Juruá, 2014.

DE OLIVEIRA, Izes Regina. Tratar a cidade como ecossistema: contribuições teórica e prática visando à sustentabilidade urbana. Revista Tecnologia e Ambiente, V. 24, 2018. Disponível em: http://periodicos.unesc.net/tecnoambiente/article/view/4365 Acesso 15 outubro 2020.

DIAS, Genebaldo Freire. Pegada ecológica e sustentabilidade humana. São Paulo: Gaia, 2002.

EINSTEIN, Albert. A teoria da Relatividade Especial e Geral. Rio de Janeiro: Contraponto, 1999.

FENSTERSEIFER, Tiago. Direitos fundamentais e proteção do ambiente: a dimensão ecológica da dignidade humana no marco jurídico-constitucional do Estado Socioambiental de Direito. Porto alegre: Livraria do Advogado, 2008.

FENSTERSEIFER, Tiago; SARLET, Ingo. Direito Constitucional Ambiental: constituição direitos fundamentais e proteção do ambiente. Revistas dos Tribunais, São Paulo, 2017

FRANCO, Maria de Assunção Ribeiro. Planejamento ambiental para a cidade sustentável. São Paulo: Annablume, 2000.

FRANCO, Maria de Assunção Ribeiro. Desenho ambiental: uma introdução à arquitetura da paisagem com o paradigma ecológico. 2a edição, São Paulo: Annablume, 2008.

GEHL, Jan. Cidade para pessoas. 2* edição, São Paulo: Perspectiva, 2013.

GIRARDET, Herbert. Criar Cidades Sustentáveis. Coleção: Cadernos Schumacher para a Sustentabilidade, Lisboa: Editora Sempre em pé, 2007.

GIRARDET, H. Regenerative Cities. World Future Council, Hamburgo, 2010. Disponível em: http://www.worldfuturecouncil.org/wp-content/uploads/2016/01/WFC_2010_Regenerative_Cities.pdf Acesso: 15 agosto 2017. 
GUATARRI, Félix. As três ecologias. 15a ed. Campinas: Papirus, 1990.

HARDIN, Garrett. The tragedy of the commons. Revista Science, n. 3859, p. 1243-1248, v. 162, Dec. 1968.

HAWKING, Stephen. $O$ Universo numa casca de noz. São Paulo: Mandarin, 2001.

HEISENBERG, Werner. Física e Filosofia. Brasília: Ed. Universidade de Brasília, 3. ed.,1995.

HEISENBERG, Werner. A parte e o todo: encontros e conversas sobre física, filosofia, religião e política. Rio de Janeiro: Contraponto, 1996.

HESSE, Konrad. A força Normativa da constituição. Porto alegre: Sergio Antônio Fabris Editor, 1991.

HOBBES, Thomas. Leviatã: ou Matéria, Forma e Poder de um Estado Eclesiástico e Civil. São Paulo: EDIPRO, 2015.

IBGE - Instituto Brasileiro de Geografia e Estatística. Quase dois terços das favelas estão a menos de dois quilômetros de hospitais. - Agência de Notícias em 22 maio 2020. Disponível em: https://agenciadenoticias.ibge.gov.br/agencia-noticias/2012-agencia-de-noticias/noticias/27728quase-dois-tercos-das-favelas-estao-a-menos-de-dois-quilometros-de-hospitais Acesso: 24 junho 2020

IBGE - Instituto Brasileiro de Geografia e Estatística. Números do Censo 2020. Disponível em: https://censo2020.ibge.gov.br/sobre/numeros-do-censo.html Acesso: 08 junho 2020.

IBGE - Instituto Brasileiro de Geografia e Estatística. População rural e urbana. 2015. Disponível em: https://educa.ibge.gov.br/jovens/conheca-o-brasil/populacao/18313-populacao-rural-e-urbana.html Acesso: 14 outubro 2020

IPEA - Instituto de Pesquisa Econômica Aplicada. Investimento em habitação cresce $785 \%$ em sete anos, aponta IPEA. Disponível em: https://www.ipea.gov.br/portal/index.php?option=com_alphacontent\&ordering=3\&limitstart=7600\&li mit=10\&ltemid=1\#: :text=0\%20deficit\%20habitacional\%20brasileiro\%20\%C3\%A9,9\%25\%20do\%20tota I\%20de\%20domic\%C3\%ADlios Acesso 14 outubro 2020.

JACOBS, Jane. Morte e vida de grandes cidades. São Paulo: Martins Fontes, 2001.

LASSALE, Ferdinand. O que é uma constituição. Campinas: Editora Minelli, 2005.

KRAUSE Cleandro; BALBIM, Renato e LIMA NETO, Vicente Correia. Para além do Minha Casa Minha Vida: uma política de habitação de interesse social? In: IPEA - Instituto de Pesquisa Econômica Aplicada. Brasil em desenvolvimento 2014: estado, planejamento e políticas públicas. CAPÍTULO 8, p. 191 - 229. Disponível em: http://repositorio.ipea.gov.br/bitstream/11058/3605/1/Livro_Brasil\%20em\%20desenvolvimento_2014 _Estado\%20planejamento\%20e\%20pol\%C3\%ADticas\%20p\%C3\%BAblicas_v.\%202.pdf Acesso: 16 outubro 2020

LEFEBVRE, Henri. A cidade do capital. Rio de Janeiro: DP\&A, 1999.

LOVELOCK, James. A vingança de gaia. Rio de Janeiro: intrínseca, 2006. 
MARICATO, Ermínia. \# não faltam leis. Meia Hora com o BrCidades. Webinar em: 29 maio 2020. Link: http://www.fna.org.br/2020/05/29/br-cidades-promove-live-com-erminia-maricato/

MATURANA, Humberto; VARELA, Francisco. A árvore do conhecimento: as bases biológicas da compreensão humana. São Paulo: Athena, 2001.

MEADOWS, Donella $\mathrm{H}$. Limites do crescimento um relatório para o projeto do clube de Roma sobre o dilema da humanidade. São Paulo: Perspectiva, 1973. 200 p. (Coleção debates)

MEIRELLES, Renato. \& ATHAYDE, Celso. Um país chamado favela - a maior pesquisa já feita sobre a favela brasileira. São Paulo: Editora Gente, 2014.

MILIOLI, Geraldo. Abordagem Ecossistêmica para a Mineração: uma Perspectiva Comparativa para Brasil e Canadá. Tese (Doutorado em Engenharia de Produção e Sistemas). Universidade Federal de Santa Catarina, Florianópolis, $1999 . \quad$ Disponível em: https://repositorio.ufsc.br/handle/123456789/80493 Acesso 30 junho 2020

MENEGAT, Rualdo; ALMEIDA, Gerson. Sustentabilidade, democracia e gestão ambiental. In: MENEGAT e ALMEIDA (orgs.). Desenvolvimento Sustentável e Gestão Ambiental nas Cidades: Estratégias a partir de Porto Alegre. POAlegre: UFRGS Editora, 2004.

MORIN, Edgar. Sociologia: a sociologia do microssocial ao macroplanetário. Portugal: publicações Europa-América, 1984.

MORIN, Edgar. Introdução ao pensamento complexo. Porto Alegre: Sulina, 2005a.

MORIN, Edgar. O Método 1: A natureza da natureza. Porto Alegre: Sulina, 2005b.

MORIN, Edgar. O Método 2: A vida da vida. Porto Alegre: Sulina, 2005c.

MORIN, Edgar. O Método 3. O conhecimento do conhecimento. Porto Alegre: Sulina, 2005d.

MORIN, Edgar. O Método 4. As ideias. Porto Alegre: Sulina, 2005e.

MORIN, Edgar. O Método 5: A humanidade da humanidade. Porto Alegre: Sulina, $2005 \mathrm{f}$.

MORIN, Edgar. O Método 6: Ética. Porto Alegre: Sulina, 2005g.

MORIN, Edgar. Restricted complexity, General complexity. Presented at the Colloquium “Intelligence de la complexit": Epistemologie et pragmatique", Cerisy-La-Salle, France, June 26th, 2005h.

MORIN, Edgar. Ciência com Consciência. Rio de Janeiro: Bertrand Brasil, 2005i.

MORIN, Edgar. A via para o futuro da humanidade. Rio de Janeiro: Bertrand Brasil, 2013.

MORIN, Edgar. Rumo ao abismo?: ensaio sobre o destino da humanidade. Rio de Janeiro: Bertrand Brasil, 2011.

MORIN, Edgar. Webinar Veredas Para o Futuro: O Mundo Pós Covid-19. UnBTV, 05 junho 2020. Disponível em: https://www.youtube.com/watch?v=qICoQPsIFIc 
MORIN, Edgar; KERN, A. Terra-Pátria. Porto Alegre: Sulina, 2003.

NEIDERUD, Carl Johan. How urbanization affects the epidemiology of emerging infectious diseases. Infection Ecology and Epidemiology. 2015; 5: 10.3402 / iee.v5.27060. Publicado online em: 24 junho 2015. Disponível em: https://www.ncbi.nlm.nih.gov/pmc/articles/PMC4481042/ Acesso: 06 abril 2020

NEWMAN, Peter. Greening the city: the ecological and human dimensions of the city can be part of town planning. In: ROSELAND, Mark (org.). Eco - City Dimensions. Canadá: New Society Publishers. 1997.

NEWMAN, Peter e BATLLEY, Timothy. Biophilic Cities are sustentainable, resilient cities. Revista Sustentainability, 2013, 5, 3328-3345; Disponível em: http://www.mdpi.com/2071-1050/5/8/3328> Acesso em 10/07/2020.

NICOLESCU, Basarab, 2005. O Manifesto da Transdisciplinaridade. 3*Ed. São Paulo: Triom.

NU - BRASIL. FAO lista sete conexões e contribuições do ecossistema animal ou vegetal. 27 maio 2019. Disponível em: https://nacoesunidas.org/fao-lista-sete-conexoes-e-contribuicoes-do-ecossistemaanimal-ou-vegetal/ Acesso: 12 julho 2019

NU - BRASIL. Falta de água e saneamento deixa milhões de vidas em risco no mundo, diz OMS. 2019 Disponível em: https://nacoesunidas.org/falta-de-agua-e-saneamento-deixa-milhoes-de-vidas-emrisco-no-mundo-diz-oms/ Acesso: 12 julho 2019

OMS - Organização Mundial da Saúde. Corona vírus - Covid-19. Disponível em: https://saude.gov.br/component/tags/tag/oms Acesso: 05 abril 2020.

OXFAM. Bilionários da América Latina e do Caribe aumentaram fortuna em US\$ 48,2 bilhões durante a pandemia, enquanto maioria da população perdeu emprego e renda. 27 julho 2020. Disponível: https://www.oxfam.org.br/noticias/bilionarios-da-america-latina-e-do-caribe-aumentaram-fortunaem-us-482-bilhoes-durante-a-pandemia-enquanto-maioria-da-populacao-perdeu-emprego-e-renda/ Acesso 29 julho 2020

PETRELLA, Riccardo. Água: 27 teses subversivas. Revista IHU on-line, 27 março 2018. Disponível em: http://www.ihu.unisinos.br/78-noticias/577376-agua-27-teses-subversivas Acesso: 22 março 2019

PNUD - Programa das Nações Unidas para o Desenvolvimento. PNUD apresenta Relatório de Desenvolvimento Humano 2019 com dados de 189 países. Disponível em: https://www.br.undp.org/content/brazil/pt/home/presscenter/articles/2019/pnud-apresentarelatorio-de-desenvolvimento-humano-2019-com-dado.html Acesso: 10 janeiro 2020

PRIGOGINE, Ilya. Ciência, Razão e Paixão. 2ª Ed. São Paulo: Editora Livraria da Física, 2009.

RIFKIN, Jeremy. Estamos diante da ameaça de uma extinção e as pessoas nem sequer sabem. Revista IHU, Entrevista, 24 abril 2020. Disponível em: http://www.ihu.unisinos.br/78-noticias/598316-estamosdiante-da-ameaca-de-uma-extincao-e-as-pessoas-nem-sequer-sabem-entrevista-com-jeremy-rifkin Acesso: 25 abril 2020 
ROGERS, Richard \& GUMUCHDJIAN, Philipi. Cidades para um pequeno planeta. Barcelona: Ed Gustavo Gilli, SA. 2001.

RUEDA, Salvador. Modelos de ciudad: indicadores básicos. Quaderns d'arquitectura i urbanisme, Barcelona, n.2000, p.25-32, 2000

SANTOS, Boaventura de Souza. A Cruel Pedagogia do Vírus. Coimbra, Portugal: Edições Almedina, 2020.

SANTOS, Milton. Manual de geografia urbana. São Paulo: Editora da Universidade de São Paulo, 2012.

SENADO. Brasil tem $48 \%$ da população sem coleta de esgoto, diz Instituto Trata Brasil. Agência Senado. Disponível em: https://www12.senado.leg.br/noticias/materias/2019/09/25/brasil-tem-48-dapopulacao-sem-coleta-de-esgoto-diz-instituto-trata-brasil Acesso 23 outubro 2020

SOUZA, Marcelo Lopes de. Mudar a cidade: uma introdução crítica ao planejamento e à gestão urbanos. 4a Ed. - Rio de Janeiro; Bertrand Brasil, 2006.

SMITH, Adam. Riqueza das nações. Lisboa: Fundação Calouste Gulbenkian, 1983.

TUCCl, Carlos E. M. Gestão de águas pluviais urbanas Programa de Modernização do Setor Saneamento. Secretaria Nacional de Saneamento Ambiental - Brasília: Ministério das Cidades. 4o volume, 194p., 2006. www.capacidades.gov.br/media/doc/acervo/06906898a257ceb3ec8687675e9e36c8.pdf

UN-HABITAT. Relatório das cidades mundiais 2016. Disponível em: https://twitter.com/search?q=WorldCitiesReport2016 Acesso: 29/06/2020

WHO, UN-HABITAT, 2010. Hidden Cities: Unmasking and overcoming health inequities in urban settings. Disponível em: http://www.who.int/kobe_centre/publications/hidden_cities2010/en/ Acesso: 23 abril 2020

WHO - ORGANIZACION MUNDIAL DE LA SALUD. Las 10 principales causas de defunción. Em 24 de mayo de 2018. Disponível em: https://www.who.int/es/news-room/fact-sheets/detail/the-top-10-causes-ofdeath Acesso: 22 abril 2020

\section{Sobre os autores:}

\section{Caroline Vieira Ruschel}

Pós - Doutoranda em Ciências Ambientais da Universidade do Extremo Sul Catarinense. Doutora em Direito pela Universidade Federal de Santa Catarina. Mestre em Direito pela Universidade Federal de Santa Catarina. Extensão Universitária em Direito e Meio Ambiente na Universidade de Tübingen - Alemanha. Professora do Programa de Mestrado em Políticas Públicas da Universidade do Vale do Itajaí - UNIVALI. Professora de Direito Ambiental da Universidade do Vale do Itajaí - UNIVALI. Pesquisadora de Direito Ambiental, Direito Constitucional. Advogada. Universidade do Vale do Itajaí, Itajaí, SC, Brasil

Lattes: http://lattes.cnpq.br/4746435495067413 Orcid: https://orcid.org/0000-0002-4263-850X

E-mail: carollineruschel@carollineruschel.com 


\section{Geraldo Milioli}

Sociólogo, Dr. Professor/Pesquisador do Programa de Pós-Graduação em Ciência Ambientais (PPGCA), Coordenador do Laboratório de Sociedade, Desenvolvimento e Meio Ambiente (LABSDMA), Universidade do Extremo Sul Catarinense (UNESC). Universidade do Extremo Sul Catarinense - UNESC, Criciúma, SC, Brasil Lattes: http://lattes.cnpq.br/2731977737884111 Orcid: https://orcid.org/0000-0001-5224-2042 E-mail:gmi@unesc.net

\section{Izes Regina de Oliveira}

Doutoranda em Ciências Ambientais e Mestre em Ciências Ambientais pela UNESC. Arquiteta e Urbanista. Membro do Laboratório Desenvolvimento, Sociedade e Meio Ambiente da Programa de Pós Graduação em Ciências Ambientais da UNESC. Universidade do Extremo Sul Catarinense - UNESC, Criciúma, SC, Brasil

Lattes: http://lattes.cnpq.br/0186904659069663 Orcid: https://orcid.org/0000-0002-7581-7432

E-mail:izesdeoliveira@hotmail.com

Os autores contribuíram igualmente para a redação do artigo. 